\title{
CARACTERIZACIÓN DE DOS BACTERIAS TERMÓFILAS (BP- 2 Y BP-4) CON CAPACIDAD PROTEOLÍTICA AISLADOS EN LOS GÉISERES DE CANDARAVE. TACNA - PERÚ
}

\author{
CHARACTERIZATION OF TWO THERMOPHILIC BACTERIA (BP-2 AND \\ BP-4) PROTEOLYTIC CAPACITY WITH ISOLATED GEYSERS CANDARAVE. \\ TACNA - PERU
}

\author{
'Ana Julissa Naquiche Calero, ${ }^{1}$ Ariadna Zatyuri Zúñiga Llanos, 'Cristina Isabel Ferrer Villena, \\ Israel José Salazar Quispe, 'Helena Beatriz Zapata Málaga y ${ }^{2}$ Roberto Castellanos Cabrera.
}

\section{RESUMEN}

El presente trabajo estudia las proteasas alcalinas producidas por dos bacterias termófilas designadas como BP-2 y BP-4. Estas fueron aisladas de sedimentos de los géiseres de Candarave, mostrando capacidad proteolítica en medio sólido. La cepa BP-2 mostró un diámetro de $46 \mathrm{~mm}$ del halo de hidrólisis a $50^{\circ} \mathrm{C}$, mientras que la cepa $\mathrm{BP}-4$ mostró un diámetro de $85 \mathrm{~mm}$ del halo de hidrólisis a $60^{\circ} \mathrm{C}$. Las bacterias seleccionadas BP-2 y BP-4 degradaron $2,9 \mathrm{~g} / \mathrm{L}$ de caseína en un tiempo estimado de 51 horas de incubación y $1,5 \mathrm{~g} / \mathrm{L}$ de caseina en 52 horas de incubación, respectivamente (concentración inicial de $10 \mathrm{~g} / \mathrm{L}$ de caseina). La máxima actividad proteolítica se alcanzó al final de la fase logaritmica y comienzo de la fase estacionaria en las dos bacterias. Los extractos proteolíticos producidos por las bacterias $\mathrm{BP}-2$ y BP-4 actuaron a una temperatura óptima estimada de $57^{\circ} \mathrm{C}$ y $64^{\circ} \mathrm{C}$, con un pH óptimo alcalino de 7,7 y 8,0 respectivamente. Del análisis de las secuencias del gen ARNr 165 de cada bacteria se determinó que la bacteria BP-2 tiene $99 \%$ de identidad con la especie Bacillus licheniformis y la bacteria BP-4 tiene un $99 \%$ de identidad con la especie Geobacillus thermoparaffinivorans.

Palabras claves: Proteasas alcalinas, bacteria termófila, Bacillus licheniformis, Geobacillus thermoparaffinivorans, ARNr 165.

\section{ABSTRACT}

This paper studies the alkaline proteases produced by thermophilic bacteria designated as BP-2 and BP-4. These were isolated from sediments Candarave geysers, which were shown to have proteolytic capacity on solid medium. BP- 2 strain had a diameter of $46 \mathrm{~mm}$ the hydrolysis halo at $50^{\circ} \mathrm{C}$, while $\mathrm{BP}-4$ strain showed a diameter of $85 \mathrm{~mm}$ the hydrolysis halo at $60^{\circ} \mathrm{C}$. Bacteria selected BP-2 and BP-4 degraded $2,9 \mathrm{~g} / \mathrm{L}$ casein in an estimated 51 hour incubation time and $1,5 \mathrm{~g} / \mathrm{L}$ casein in 52 hours of incubation, respectively (initial concentration of $10 \mathrm{~g} / \mathrm{L}$ casein). The maximum proteolytic activity was reached at the end of the log phase and early stationary phase in both bacteria. Proteolytic extracts produced by BP-2 and BP-4 bacteria acted to an estimated optimum temperature of $57^{\circ} \mathrm{C}$ and $64{ }^{\circ} \mathrm{C}$, with an alkaline $\mathrm{pH}$ optimum of 7,7 and 8,0 respectively. Sequence analysis of the $16 \mathrm{~S}$ rRNA gene of each bacterium was determined that the BP-2 bacterium has $99 \%$ identity to the species Bacillus licheniformis bacteria and BP-4 have $99 \%$ identity with Geobacillus thermoparaffinivorans species.

Keywords: Alkaline proteases, thermophilic bacterium, Bacillus licheniformis, Geobacillus thermoparaffinivorans, 16S rRNA.

\section{INTRODUCCIÓN}

Los termófilos son microorganismos que están adaptados para crecer óptimamente a temperaturas altas $\left(45^{\circ} \mathrm{C}\right.$ a $110^{\circ} \mathrm{C}$ ) (Castillo, 2005). Como consecuencia, estos poseen propiedades macromoleculares únicas a altas temperaturas ya que poseen elevadas tasas metabólicas, sus enzimas físicamente y químicamente estables con altos rendimientos del producto final (Kikani et al., 2010). Las bacterias termófilas son las principales fuentes de enzimas termoestables, suficientemente ventajosas para la industria (Kikani et al., 2010).

Debido al crecimiento de la industrialización, la demanda de enzimas termoestables ha aumentado enormemente, por su alta termoestabilidad y la viabilidad de los procesos involucrados. Las proteasas constituyen una de las principales enzimas para la industria, alcanzando más del $60 \%$ en el mercado mundial. Se utiliza especialmente en la industria alimentaria, farmacéutica, textil y cuero (Rao et al., 1998).

El presente trabajo tiene como objetivo principal caracterizar la capacidad proteolítica de dos bacterias termófilas (BP-2 y BP-4) aisladas en los géiseres de CalientesCandarave, Tacna-Perú, lugar más alto del mundo (Cruz et al., 2010) por lo que es de gran importancia e interés cientifi-

\footnotetext{
'Biólogo Microbiólogo. Laboratorio de Bioquímica y Nutrición, Facultad de Ciencias de la Universidad Nacional Jorge Basadre Grohmann. Tacna-Perú "Magister en Bioquímica, Biólogo Pesquero. Jefe del Laboratorio de Bioquímica y Nutrición, Docente de la Facultad de Ciencias de la Universidad Nacional Jorge Basadre Grohmann. Tacna-Perú
} 
Naquiche, A. et al. Caracterización de dos bacterias termófilas (BP-2 y BP-4) con capacidad proteolítica aislados en los géiseres de Candarave. Tacna-Perú.

co conocer la biodiversidad de este ambiente.

\section{MATERIAL Y MÉTODOS}

\section{Aislamiento y actividad enzimática en medio sólido}

Las bacterias (BP-2 y BP-4) fueron aisladas de los sedimentos de los géiseres de Calientes, Candarave, ubicados en la Cordillera Occidental, en el sur del Perú, a $17^{\circ} 15^{\prime}$ 30" de latitud sur a 4400 m.s.n.m. (Cruz et al., 2010). En dicha zona se muestrearon ocho géiseres, cuya temperatura varió entre 50 y $84^{\circ} \mathrm{C}$ y el pH entre 6,2 y 7,5 .

Las muestras fueron pre-enriquecidas en medio LB (Triptona $10 \mathrm{~g}$, extracto de levadura $5 \mathrm{~g}$ y NaCl $10 \mathrm{~g}$ ) a un $\mathrm{pH}$ de 7 (Remigio et al., 2012), incubándose a $60^{\circ} \mathrm{C}$ por 48 horas. Posteriormente dichas muestras han sido sembradas en agar (leche descremada, $\mathrm{NaCl}_{1} \mathrm{~g}, \mathrm{~K}_{2} \mathrm{HPO}_{4} 1 \mathrm{~g}, \mathrm{MgSO}_{4} .7 \mathrm{H}_{2} \mathrm{O}$, extracto de levadura $0,5 \mathrm{~g}$ y agar $15 \mathrm{~g}$ ) (Zilda et al., 2012) e incubadas a $60^{\circ} \mathrm{C}$ por 48 horas, con el propósito de observar el halo de hidrólisis. Las bacterias que presentaron halo de hidrólisis fueron purificadas y conservadas medio sólido LB. Se evaluó el halo de hidrólisis de las bacterias seleccionadas a 50 y $60^{\circ} \mathrm{C}$ por 96 horas.

\section{Evaluación de la degradación de la caseína}

Los Matraces de $500 \mathrm{~mL}$ con $250 \mathrm{~mL}$ de medio de producción de proteasa (caseina $10 \mathrm{~g} / \mathrm{L}$ en buffer Tris $\mathrm{HCl}$, $\mathrm{pH} 7,2)$ fueron inoculados en un $10 \%(\mathrm{v} / \mathrm{v})$ de caldo LB con crecimiento bacteriano de $10^{7} \mathrm{cel} / \mathrm{mL}$ (Ghobadi et al., 2009).

Se determinó la concentración de proteína inicial y final durante 72 horas, evaluándose en un intervalo de 12 horas, según el método de Bradford (Bradford, 1976). Además se realizó el recuento de bacterias utilizando la cámara de Neubawer. El extracto crudo se logró obtener mediante la centrifugación del medio de fermentación a $7000 \mathrm{rpm}$ durante $30 \mathrm{~min}$. El sobrenadante se utilizó para el ensayo de la actividad proteolítica. Para lo cual se añadió $100 \mu \mathrm{L}$ de extracto crudo en $1000 \mu \mathrm{L}$ con $1 \%$ de caseína en buffer fosfato 50 $\mathrm{mM}$ (pH 6 y 7 ) y buffer Tris $\mathrm{HCl} 50 \mathrm{mM}$ (pH 8 y 9) (Aqel et al., 2012), determinándose el $\mathrm{pH}$ óptimo de la actividad a temperatura de 55 y $60^{\circ} \mathrm{C}$ para las bacterias BP-2 y BP-4 respectivamente. Para la determinación de la temperatura óptima se evaluó los valores de $45,55,65 y y^{\circ} \mathrm{C}$ con un $\mathrm{pH}$ de 7,2 .

\section{Extracción de ADN y análisis del secuenciamiento del ARNr 16S}

Para la extracción del ADN genómico de las bacterias termófilas proteolíticas seleccionadas, se utilizó el kit Wizard Genomic DNA Purification, siguiendo el protocolo del fabricante. A partir del ADN genómico se obtuvo los genes ARNr 16S de cada bacteria seleccionada por Macrogen Inc. Las secuencias de nucleótidos fueron comparadas a la base de datos del NCBI GenBank (The National center for Biotecnology Information) usando BLAST N (Basic Local Alignment Search Tool).

\section{RESULTADOS}

Aislamiento y actividad enzimática en medio sólido Luego de seleccionar las dos bacterias termófilas en medio agar leche descremada, dichas bacterias presentaron un mayor halo de hidrólisis, indicando la hidrólisis de la caseina producida por la enzima proteasa.

La bacteria BP-2 mostró un mayor diámetro de halo de hidrólisis a $50^{\circ} \mathrm{C}(46 \mathrm{~mm})$ y la bacteria BP-4 mostró un diámetro mayor a $60^{\circ} \mathrm{C}(85 \mathrm{~mm})$.

\section{Caracterización de las bacterias proteolíticas}

El crecimiento bacteriano y la actividad enzimática evaluada por la degradación de la caseína de los cultivos seleccionados se incrementaron gradualmente a medida que avanzó el tiempo de incubación, mostrando la máxima actividad de la enzima después de las 48 horas de incubación al inicio de la fase estacionaria del crecimiento bacteriano. (Figura 1).

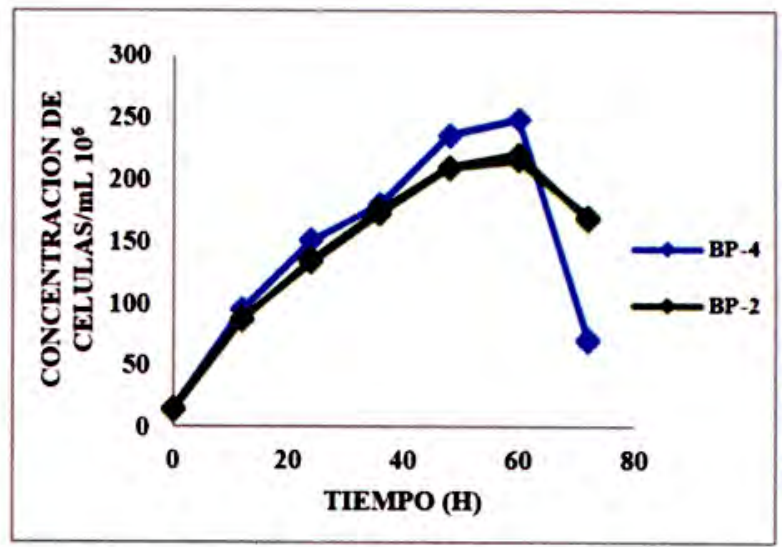

Figura 1. Crecimiento bacteriano de los cultivos BP-2 y BP-4 en el medio de producción.

Las bacterias BP-2 y BP-4 degradaron $2,9 \mathrm{~g} / \mathrm{L}$ de caseina, en un tiempo estimado de 51 horas de incubación y $1,5 \mathrm{~g} / \mathrm{L}$ de caseína a las 52 horas de incubación, respectivamente. (Figura 2).

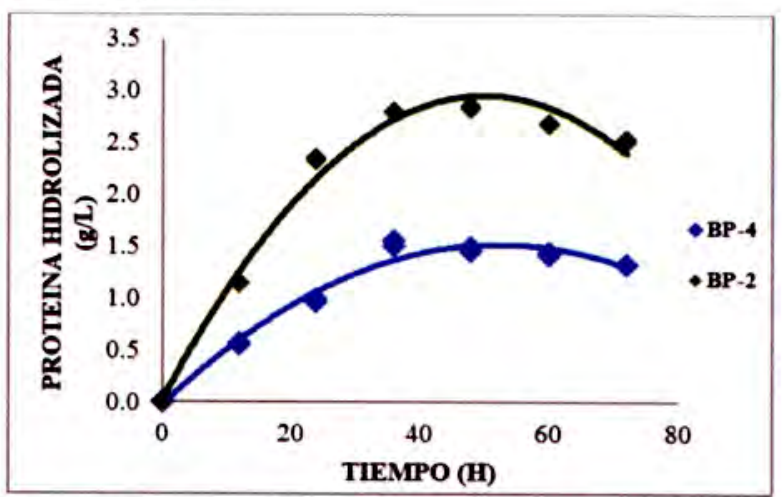

Figura 2. Proteinas hidrolizadas versus Tiempo de fermentación de los extractos proteolíticos producidos por las bacterias BP-2 y BP-4.

Determinación de las condiciones óptimas de la hidrólisis

La temperatura de hidrólisis óptima estimada obtenida de la ecuación del modelo de regresión polinomial (figura 3) resultó $57^{\circ} \mathrm{C}$ con una concentración de proteínas hidrolizadas de $0,7 \mathrm{~g} / \mathrm{L}$ para el cultivo BP- 2 y $64^{\circ} \mathrm{C}$ con una concentración de proteínas hidrolizadas de $0,6 \mathrm{~g} / \mathrm{L}$ para la 


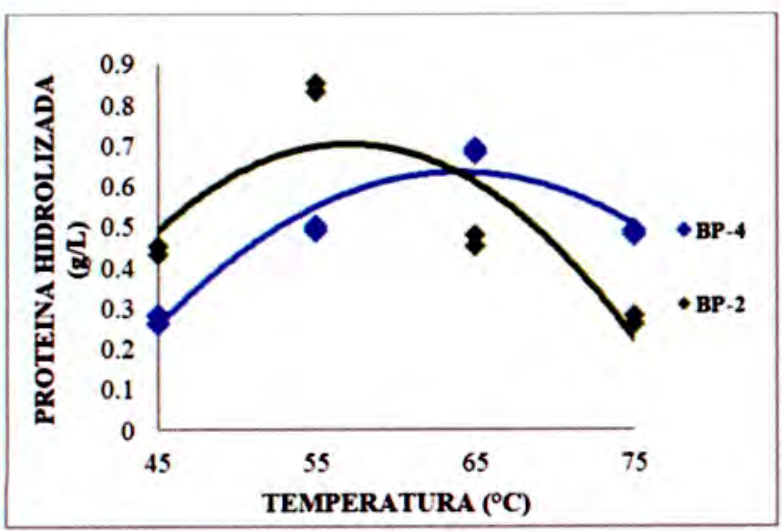

Figura 3. Proteínas hidrolizadas versus temperatura de reacción del extracto proteolítico producidos por las bacterias BP-2 y BP-4.

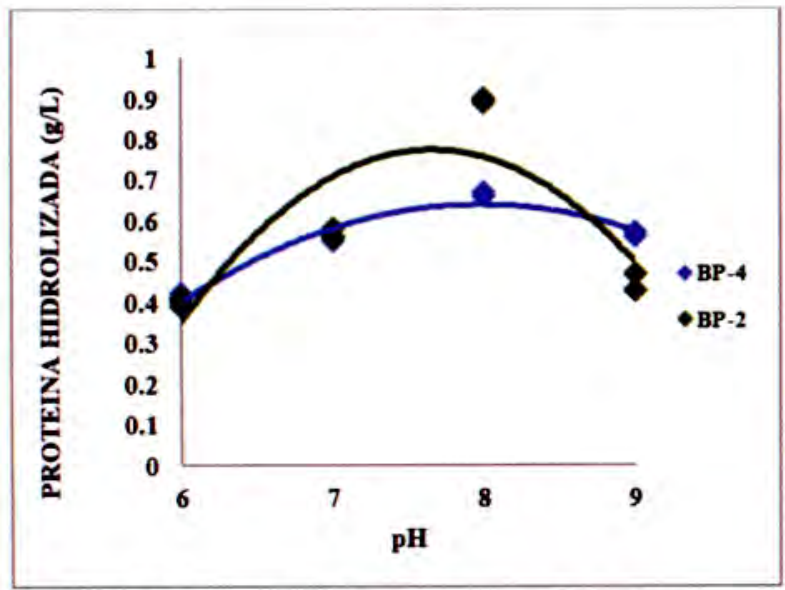

Figura 4. Proteinas hidrolizadas versus $\mathrm{pH}$ de reacción del extracto proteolítico producido por las bacterias BP-2 y BP-4.

\section{bacteria BP-4.}

El pH óptimo de reacción para el extracto proteolítico producido por el cultivos BP-2 fue de 7,7, con una concentración de proteínas hidrolizadas de $0,8 \mathrm{~g} / \mathrm{L}$ y 8,0 y una concentración de proteínas hidrolizadas de $0,6 \mathrm{~g} / \mathrm{L}$ para el cultivo BP-4 (figura 4), lo que indica que pueden ser clasificadas como proteasas alcalinas.

\section{DISCUSIÓN}

La formación del halo de hidrólisis alrededor de las colonias seleccionadas es resultante de la actividad proteolitica en medio sólido (Habib et al., 2012) a temperatura de incubación de 50 y $60^{\circ} \mathrm{C}$. Los cultivos BP-2 y BP-4 seleccionados tienen la capacidad de producir proteasas extracelulares en el medio agar leche descremada. Este es un medio complejo donde los nutrientes no se encuentran de manera libre, por lo que ambos cultivos produjeron esta enzima para obtener los nutrientes necesarios (Garcia et al., 1992).

El tiempo de incubación juega un papel importante en la producción enzimática. En el presente trabajo, la actividad máxima de la enzima y la degradación de la caseína fue observada poco después de las 48 horas de incubación, al inicio de la fase estacionaria del crecimiento bacteriano. Los cultivos BP-2 y BP-4 lograron degradar una concentración de $2,9 \mathrm{~g} / \mathrm{L}$ de caseína en un tiempo estimado de 51 horas de incubación y $1,5 \mathrm{~g} / \mathrm{L}$ de caseína a las 52 horas de incubación respectivamente. Estos resultados se ajustan con las observaciones hechas por Sevinc y Demirkan (2011) y Swamy et al. (2012) en donde la máxima actividad de la proteasa producida por Bacillus sp. y Comomonas kerstersï se produjo al final de la fase exponencial y al inicio de la fase estacionaria. Sin embargo, según Qadar et al. (2009) informó que Bacillus subtilis 3441 presentó una máxima actividad a las 72 horas. La producción de la enzima proteasa puede estar directamente vinculada con el metabolismo activo del cultivo bacteriano (Kanchana \& Padmavathy, 2010). Además, Gupta et al. (2002) informaron que la producción de proteasa extracelular está relacionada con la deficiencia de nutrientes al principio de la fase estacionaria.

En la determinación de las condiciones óptimas de hidrólisis de proteína, se obtuvo proteasas termoestables, con valores de temperatura de 57 y $64^{\circ} \mathrm{C}$ para bacterias BP-2 y BP-4, estando dentro del rango establecido por Satyanarayana et al. (2013) $\left(50\right.$ a $\left.85^{\circ} \mathrm{C}\right)$ para ser consideradas como tales. Así mismo resulta coincidente con otras investigaciones de proteasas bacterianas; reportándose una temperatura óptima de $55^{\circ} \mathrm{C}$ para Bacillus sp. PCSIR (Swamy et al., 2012) y una temperatura óptima de $60^{\circ} \mathrm{C}$ para Bacillus licheniformis (Olajuyigbe y Ajele, 2008), mientras que para las especies de Geobacillus la temperatura óptima fluctúa entre 50 y $70{ }^{\circ} \mathrm{C}$ (Hawumba et al., 2002).

El pH óptimo de la mayoría de las proteasas termófilas se ha encontrado en el rango de 6,0 a 12,0 , lo que concuerda con los resultados obtenidos para la bacteria BP-2 y BP-4 obteniéndose valores de 7,7 y 8,0 respectivamente, estos hechos indican que pueden ser clasificados como proteasas alcalinas (Rao et al., 1998). Ageitos (2011) reportó un $\mathrm{pH}$ óptimo de 6 a 7,5 para la actividad de la proteasa en Bacillus licheniformis USC 13, mientras que Zhu et al. (2007) reportaron un $\mathrm{pH}$ para la actividad proteolítica de Geobacillus sp. YMTC 1049 entre 6 a 9.

El pH óptimo es un parámetro que tiene gran relevancia para determinar el uso de la enzima, en este caso, ambas proteasas tienen gran importancia, ya que ocupan el $25 \%$ del mercado mundial de comercialización de enzimas (Rao et al., 1998). Estas propiedades de las proteasas alcalinas bacterianas las hacen adecuadas para su uso en la industria (Jisha, 2013).

La identificación de las bacterias seleccionadas fue realizada mediante el análisis de la secuencia del gen $\mathrm{ARNr}$ 16S. La identidad de las secuencias obtenidas fueron comparadas en la base de datos del National Center of Biotecbnology Information (NCBI) a través del BLAST N, resultando la bacteria BP-4 con un $99 \%$ de identidad con Geobacillus thermoparaffinivorans, lo cual concuerda con las características macroscópicas y microscópicas observadas para el género Geobacillus en la bacteria BP-4. Además, especies de Geobacillus han sido aisladas frecuentemente de aguas termales (Malhotra et al., 2000; Noorwez et al., 2006., Obeidat et al., 2012).

Mientras que para la bacteria BP-2 se obtuvo un $99 \%$ de identidad para especie Bacillus licheniformis. Las características fenotípicas reportadas por esta especie concuerdan 
Naquiche, A. et al. Caracterización de dos bacterias termófilas (BP-2 y BP-4) con capacidad proteolitica aishados en los géiseres de Candarave. Tacra-Perú.

con las características del cultivo BP-2, y es reportada como productora de proteasas (Ghumr et al., 2012).

\section{CONCLUSIONES}

Se aislaron dos bacterias termófilas productoras de proteasas alcalinas denominadas BP-2 y BP-4 a partir de los sedimentos de los géiseres de Calientes.

La bacteria BP-2 mostró un diámetro de $46 \mathrm{~mm}$ del halo de hidrólisis a $50^{\circ} \mathrm{C}$ y el cultivo BP-4 también mostró un mayor diámetro $85 \mathrm{~mm}$ del halo de hidrólisis de $60^{\circ} \mathrm{C}$.

La máxima hidrólisis de la caseína para las bacterias seleccionadas se produjo al finalizar la fase logarítmica de su crecimiento, siendo a las 51 y 52 horas de crecimiento para las bacterias BP-2 y BP-4, respectivamente.

La actividad de los extractos proteolíticos crudos, evaluada mediante la hidrólisis de la caseina, presentó una temperatura óptima estimada de 57 y $64^{\circ} \mathrm{C}$ para cada bacteria, indicando su naturaleza termocstable y un $\mathrm{pH}$ óptimo alcalino estimado de 7,7 y 8,0 .

De acuerdo al análisis de las secuencias del gen ARN 16S, las bacterias BP-2 y BP-4 tienen un $99 \%$ de identidad a las especies Bacillus licheniformis y Geobacillus thermoparaffinivorans, respectivamente.

\section{REFERENCIAS BIBLIOGRÁFICAS}

Ageitos, J.M. (2011). Punificación, caracterización y expresion beteróloga de la proteasa menor extracelular (Epr) de Bacillus licbeniformis. (Tesis doctoral). Departamento de Microbiología y Parasitología. Universidad de Santiago de Compostela Facultad de Farmacia.

Aqel, H., Al-Quadan, F., Yousef, T. (2012). A novel neutral protease from thermophilic Bacillus strain HUTBS62. J. BioSci. Biotech. 1(2): 117-123.

Bradford, M. (1976). A rapid and sensitive method for the quantification of microgram quantities of protein utilizing the principle protein dye binding. Analytical Biochem. 72: 248-254.

Castillo, F., Roldan, M.D., Huertas, M.J., Caballero, F., Moreno, C., y Luque, L.R. (2005). Biotecnología ambiental. Madrid: TébarSL. 380-386.

Cruz, V., Vargas, V. and Matsuda, K. (2010). Geochemical Characterization of Thermal Waters in the Calientes Geothermal Field, Tacna, South of Peru. Proceedings World Geothermal Congress. Bali, Indonesia.

Garcia, R., Coha, J.M., Ramírcz, P. y Contreras, G. (1992). Perfil de exoenzimas de Pseudomonas aeruginosa. Reuniones cientificas. Universidad Nacional Mayor de San Marcos. Facultad de Ciencias Biológicas.

Ghobadi, Z., S, Yaghmaei and R, HAJI. (2009). Production of Extracellular Protease and determination of optimal condition by Bacillus licheniformis. BBRC 100053. IJE Transactions B: Applications. 22: 221-228.

Ghumr, P., Shafique, M., Ishtiaq, M., Javed, I., Ahmad, B., Jamal, J., and Hameed, A. (2012). Isolation and screening of protease producing thermophilic Bacillus strains from different soil types of Pakistan. African Journal of Microbiology Research. 6(8): 16631668 .
Gupta, R., Beg, Q.K and Lorenz, P. (2002). Bacterial alkaline proteases: molecular approaches and industrial applications. App. Microbiol. Biotech. 59:15-32.

Habib, S.M., Fakhruddin, A.N., Begum, S and Ahmed, M. (2012). Isolation and screening of thermostable extracellular alkaline protease producing bacteria from tannery effluents. J. Sic. Res. 4 (2): 515-522.

Hawumba, J.F., Theron, J., Brözel, V. (2002). Thermophilic Protease producing Geobacillus from Buranga Hot Springs in Western Uganda. Current Microbiology. 45(2): 144-150.

Jisha, V.N., Smitha, R.B., Pradeep, S., Sreedevi, S., Unni, K.M., Sajith, S., Priji, P., Moolakkariyil, S.J and Sailas, B. (2013). Versatility of microbial proteases. Advances in ensyme research journal: 1 (3): 39-51 India.

Kanchana, M. and Padmavathy, S. (2010). Optimization of extracellular alkaline protease enzyme from Bacillus sp. The Bioscan, 5(1): $85-87$.

Kikani, B.A., Shukla, R.J and Singh, S.P. (2010). Biocatalytic potential of thermophilic bacteria and actinomycetes. Rajkot-360005. India.

Malhotra, R., Noorwez, S.M., Satyanarayana, T. (2000). Lett App/Microbio/31:378-384.

Noorwez, S.M., Ezhilvannan, M., Satyanarayana, T. (2006) Indian J Biotechno/ 5:337-345.

Obeidat, M., Khyami, A., Al-Zoubi and Otri. (2012). Isolation, characterization, and hydrolytic activities of Geobacillus species from Jordanian hot springs. African Journal of biotechnology. 11(25): 6763-6

Olajuyigbe, F.M., Ajele, T.O. (2005). Production dynamics of extracellular protease from Bacillus species. Afr. J. Biotecbnol., 4(8): 776-779.

Qadar S.A., Erum, S., Samina, L., Abida, A. (2009). Optimization of protease production from newly isolated strain of Bacillus sp. PCSIR EA-3. Indian J. Biotechnol $8: 286-290$.

Rao, M., Aparna, S.G., Monhini, V and Deshpande, V. (1998). Molecular and biotechnological aspects of microbial proteases. Microbiology and Molecular Biology Reviens. 62: 597-635.

Remigio, Z., Muronde, W., Holst, O and Parawira, O. (2012). Isolation and characterization of a proteaseproducing thermophilic bacterium from an African hot spring. African Journal of Biotechnology .11(62): $12571-12578$.

Satyanarayana, T., Littlechild, J., and Kawarabayasi, Y. (2013). Thermopbilic microbes in environmental and industrial biotechnology. Biotechnology of Thermoplites 2 da Edition. Netherlands: Dordrecht-Springer Science+Business Media.

Sevinc, N. and Demirkan, E. (2011) Production of Protease by Bacillus sp. N-40 Isolated from Soil and Its Enzymatic Properties. J. Biol. Environ. SCI., 5(14), 95-103.

Swamy, k., Kashyap, S., Vijay, R., Tiwari, R and Anuradha, M. (2012). Production and optimization of extra cellular protease from bacillus sp. isolated from soil. International Journal of Advanced Biotechnology and Research.3 (2): 564-569.

Zhu, W., Cha, D., Cheng, G., Peng, Q and Shen, P. (2007). Enzyme Microb Technol.40:1592-1597. 
Naquiche, A. et al. Caracterización de dos bacterias termófilas (BP-2 y BP-4) con capacidad proteolítica aislados en los géiseres de Candarave. Tacna-Perú.

Zilda, D. S., Harmayani, E., Widada, J, Asmara, W., Irianto, H.E., Patantis, G. and Fawzya, Y. N. (2012). Screening of thermostable protease producing microor- ganisms isolated from indonesian hotspring. Squalen vol. 7 núm. 3, december 2012: 105-114.

\section{Correspondencia:}

Ana Julissa Naquiche Calero: julycalero7@gmail.com

Fecha de Recepción: 15/04/2015

Roberto Castellanos Cabrera: roberto_castellanos2002@yahoo.es

Fecha de Aceptación: 16/06/2015 